\title{
Political Construction of Women in Kemiren Village
}

\author{
Puji Lestari ${ }^{1, *}$ Iwan Hardi $^{2}$, Wenny Eka ${ }^{3}$ Ferani Mulyaningsih ${ }^{4}$
}

\author{
1,2,3,4 Universitas Negeri Semarang \\ *Corresponding author. Email: pujilestarikrisbiyantoro@mail.unnes.ac.id
}

\begin{abstract}
This article explores the political construction of Osing tribe women with strong traditions, customs, and beliefs in their daily lives. The community traditions and culture usually closely related to patriarchal values. Analyzing Osing Tribe women; their political interaction, political participation is required so that description of their political construction in society is obtained, and whether there is a gender gap among women of the Osing Tribe in Kemiren Village, Banyuwangi, East Java. Peter Berger's analysis is used to dissect the phenomenon occuring in Osing Tribe women in being politically engaged. This qualitative research was designed with a phenomenological approach with a feminist perspective, examining women in Kemiren Village, the residence of the Osing Tribe community in Banyuwangi Regency. Collecting data using google form is reinforced by interviews using social media; WhatsApp, Instagram, and Facebook to informants, in order to obtain research data. Secondary data obtained from documentation of informants, online news, and several other sources.

The results of the research point out two things; 1) women's construction in Kemiren is on par with men in politics, they have the same right to be elected. Most of Kemiren's women have not been independent in making their political choices, influenced by family members, community leaders. The low level of education is one of the factors besides the notion that harmony in society is more important than politics. 2) Women carry out political interactions, communication, and participation in the social harmony that they want to maintain, in Kemiren Village. The election of women to be the head of the Kemiren village for one period indicates that in the political realm, women not marginalized in the political construction of the Osing Tribe community in Kemiren.
\end{abstract}

Keywords: politics, construction, women, Osing tribe.

\section{INTRODUCTION}

The Osing Tribe is the largest part of the Banyuwangi community that has long been inhabited by other ethnicities, which are Madurese, wong kulonan (Javanese), Balinese, Bugis, Mandar, Chinese, Arabic (Moor) and European. Epp (1849) in Indiarti (2018) identified the ancient history, in 1849, from various records about them being Blambangan people who had a population of 25,520 people or 91 percent of the total population of Banyuwangi [1].

Indiarti's search (2018) addressed that Banyuwangi's people - in a part of the book Cariyos Lampah-lampahipun Raden Mas Arya Purwalelana (pseudonym of the Regent of Kudus, RMA Condranagara V) - in the 1800s was tiyang alit (people) who is wellbehaved (sae-sae) when compared to the Madurese and Balinese who often have cases with the police. They are self-sufficient, well behaved, avoid stealing, wealthy and prosperous, and when a husband and wife habitually go to the market or other places, their houses are unoccupied and unlocked, and many of their belongings are left unattended. The ancient life describes an aftermath of the Blambangan Kingdom. The story of superiority and efficacy of the Blambangan people, both men and women, is one thing embedded from various records. For example, the milk of female slaves from Blambangan called as Tiyang Pinggir, which was highly sought after for the babies of Mataram aristocrats, the beauty and valiance of their race, even objects that were sacred to the people like those of President Soekarno. In subsequent developments, the Blambangan people were known as the Osing tribe community. Wong Osing in Banyuwangi is believed to be the heir to the ancient Blambangan culture, becoming an important actor in shaping the identity of Banyuwangi today. 
The Osing tribe women cannot be separable from their customs, traditions, cultural practices, religions, and informal institutions. Each of these causes emerges, grows, and develops beliefs that shape the pattern in which women are in the place determined by their society, as well as their rights and obligations. In general, culture is a determining factor in the formation of emerging labels for women. Everyday social reality fosters social construction, which is understood as a statement of belief and the point of view that the content of consciousness and ways of relating to others, is taught by culture [2]. Berger and Luckmann (1990) explained that social reality is a social construction created by humans, and religion is also part of culture, which is a human social construction. Society is both objective and subjective reality, as Berger stated. As an objective reality, society is beyond human being and dealing with it [3]. Meanwhile, as a subjective reality, individuals exist in society as an inseparable part. The realm of individual experience is inseparable from the social realm in which the individual is the maker of society, and society is the maker of individual. Objective and subjective reality, known in social construction theory, which points out to the meaning that objective reality is a reality beyond the human self and subjective reality resides in the human beings themselves.

There is a dialectical process between the objective and subjective realm in social construction theory, which can be categorized into three processes according to Peter Berger, i.e., externalization, objectivities, and internalization [4]. These three transcended processes form a construction in society of one subject or object being studied. In this social reality, other phenomenon's are then encountered such as political, economic, cultural, and so on. The political construction of women, thus far, cannot be separated from the continuous social process that places them in a less favorable position than men, thus women are shackled in culture [5].

The patriarchal culture that has developed in Indonesian society thus far has become a form of marginalization of women and has positioned women as the second person after men [6]. In society, women are obliged to be loyal to religion, belief or cultural system, even though they are often aware that they have been wronged and or even their rights are violated. Winter explores how many women's rights have been distorted, biased, and subjected to violations in the practices, religious rituals and traditions of their societies [7]. Religious and cultural factors are often used to determine the level of representation of the women [8].

The patriarchal reality has been accused of causing women to be increasingly marginalized in various social and political accesses in their society. Patriarchal culture is often "main suspect" when it comes to the question of why women do not take part in various social and political activities [9]. Regarding the patriarchal system, radical feminists regard that in every institution and every society's most basic structure there is a system of oppression in which certain people dominate others. The most basic structure of oppression is contained in a patriarchal system, oppression of men over women [10]. Patriarchal culture restricts the space for women to move, as in this patriarchal culture, men are positioned as central figures with the main authority in social organizations [11]. Fineman described the state of women in a traditional patriarchal system in which men from the class that traditionally have privileges. The existence of women is often considered "safe" if they exist and live in their family and community, the patriarchal system will protect them [12]. Conversely, women who deviate from traditional patriarchal families will suffer from legal system [13]. Women as "konco wingking" in Javanese society still vaguely arise and fall [14]. Megawangi explained that the view of feminism regarding ideology of patriarchy is negative in which it has placed women in a subordinate position, i.e. lower than men [15].

The existence of women is often considered "safe" if they exist and live in their family and community, the patriarchal system will protect them. Women who deviate from traditional patriarchal families will suffer from legal system. It is what Beauvoir also mentioned in his description of women in his book entitled The Second Sex that women live under the shadow of men [16]. As a result, women are not independent in their lives in society due to the construction that is formed against them. These are influenced by the distribution of performance that places them in all domestic matters [17], unequal power relations thus far, which places women unfairly [18], they are only educated to take care of matters related to sumur, kasur, and dapur (livelihood, bed, and kitchenette) [19], women cannot hold the highest positions in the religious realm [20]. The things that happen to women, in the end also affect women's behavior in being politically engaged.

As well as Lovenduski, he also explained about the social obstacles faced by women in becoming political actors. These social obstacles; first, the required resources to enter politics that belong to women are weaker. Second, various lifestyle constraints leave women with little time for politics. Women that reduce their time for other activities typically carry out family and other duties demanding their full attention. Third, political duties are categorized as men's duties that prevent women from pursuing political careers and also hinder the recruitment of those who come forward [21]. 
This research observed the political construction of women in the Osing in Kemiren Village done through observing at the position and role of women in politics and the influencing factors. Analyzing women's knowledge about politics, political communication, and women's political participation in order to obtain a description of their political construction in society, and whether there is a gender gap among women of the Osing Tribe in Kemiren Village, Banyuwangi, East Java.

\section{METHOD}

The phenomenological approach using Peter Berger's social construction analysis was used in this qualitative research, in order to describe and study various phenomenons related to knowledge, participation and political communication of the Osing Tribe women. The feminist perspective was used to reveal the gender gap in politics or not for Osing women.

Collecting data using google form was extended by interviews using social media: WhatsApp, Instagram, and Facebook to informants, in order to obtain research data.
Data sources were obtained from primary sources, i.e. female informants, political party figures, and the Osing people who live in Kemiren Village, Glagah District, Banyuwangi Regency. Several literatures, articles, scientific journals, and research results related to the Osing Tribe women are sources of secondary data. Data analysis and interpretation in this study will be analyzed by means of transcription and categorization based on themes, then described and interpreted, so that the meaning of the data is directly related to the phenomenon extracted from the Osing Tribe women being politically engaged.

\section{RESULT AND DISCUSSION}

Osing community in Kemiren who live in two Hamlets of Kedaleman and Krajan, are administratively divided into 7 (seven) RW (Community Group Based on Hamlet) and 28 (twenty eight) RT (Community Group Based on Close Area). Some Osing women in Kemiren, are working women and have enough experience. This can be seen from the data below;

Table 1. Number of Female Population by Job Classification

\begin{tabular}{|l|l|}
\hline Job Classification & Amount \\
\hline Farmers & 498 \\
\hline Teachers & 15 \\
\hline Public Employees & 98 \\
\hline Household & 256 \\
\hline Students & 425 \\
\hline Taylors & 15 \\
\hline Others & 22 \\
\hline Total & 1.329 \\
\hline
\end{tabular}

Source: demography data of Kemiren Village (2020)

In every political event, women participate actively. In 2018 Regional Head Elections, there were 1,156 more female voters more than 924 men. This article describes two findings. First, knowledge, the views of Kemiren people are about the equal standing between men and women deeply influenced by their customs and traditions. Equal relationships demonstrated and taught through symbols in traditions where women and men play an important role in life. Although at the district, provincial and national levels there are no Kemiren women sitting in the legislature, but at least the egalitarian views of Osing community in Kemiren proved when they once elected a female Village Chief.

Kemiren women's political choices are still not determined independently. Their choices are influenced by; family members (husband, son, etc.); community leaders, as well as the choice of shamans or Osing traditional heads in Kemiren. The other figures who followed his political choices, and as happened in 1999 when Kyai Abdul Ghofar an Osing community leader became a campaigner for one of the parties, and eventually won votes in Kemiren (Angin and Febrina, 2004) [22]. This political choice is still nondependent because in the view of Osing people, politics has not had a significant influence on their lives, even assuming politics can damage harmony in people's lives. In addition, the largely low level of women's education, which can be observed from the data below, also influences Osing women's political views. 
Table 2. Number of Women Population by Level of Education

\begin{tabular}{|l|c|}
\hline \multicolumn{1}{|c|}{ Education Levels } & Amount \\
\hline Kindergarten/ Nursery Schools & 60 \\
\hline Elementary Schools & 328 \\
\hline Junior High Schools & 348 \\
\hline Senior High Schools & 278 \\
\hline Not Schools & 37 \\
\hline Not Finished Elementary School & 278 \\
\hline Total & 1.329 \\
\hline
\end{tabular}

Source: Demography Data In Kemiren Village (2020)

Women voters in political elections who did not finish elementary school and finished elementary school especially over 40 years old is what mostly rely on other people's political choices.

The second finding in this study is that women carry out political communication and political participation in order to create social harmony and togetherness in Kemiren Village. It is inevitable that the men in the family (husband, father) are important in making decisions over Osing women in the public realm. It does not mean, however, that women are incapable of being independent and it does not mean that men restrict their freedom. Osing community is educated as an independent and open community group. Richard Hakluyt (1904) in Wiwit Indarti (2018), identified the character, language, and customs of Osing people as very different from other Javanese; they are known to have high self-esteem, honest, persistent, and reluctant to work for Europeans. They are prosperous farmers due to their ownership of large agricultural land [23]. This identity still attached to the Osing community today, which has social independence.

Based on the results of interviews with informants, harmony in society is more important to be materialized so that the political realm is not considered the major thing, if it destroys social harmony. The struggles in each succession of local political leadership in Banyuwangi and at the national level cause no rumbling and even conflict in Kemiren. How do they respond? They are open to anyone and any candidates from any party who want to get their support during the elections. Women will openly accept political campaigns from any party and support anyone who brings goodness to their lives, especially candidates who aim to advance Osing culture. The open nature of Osing people is often interpreted as support parties. Even though this is not always the case, Osing women argue that none is able to suppress their political choices. Several female informants explained that thus far they are free to make political choices and candidates who became political contestants. Osing women have different views on politics, most of which express positive views about politics. They always expect changes to occur through their political views and choices.

A female village head just ended her position on October 10, 2019. The election of women to be the head of the village of Kemiren for one period indicates that in the political realm, women are not marginalized in the political construction of Osing Tribe community. Osing community in Kemiren has no problem with women participating in the political process. However, society generally argues that no matter how high a woman's position is in social and political life, they should not abandon their duties in the family. Therefore, it is no problem when women are politically engaged as long as they keep working on their duties. In addition, women must continue to pay attention to their actions in politics so that they continue to act in the right direction. They must be able to present their dual role in public affairs (work) and never abandon their domestic affairs in the family.

How do women participating in politics in Kemiren? It is accustomed for Osing women to enter the public realm, which is politics. A female village head has just ended her position on October 10, 2019. The election of women to be the head of Kemiren village for one period shows that in the political sphere, women are not marginalized in the political construction of the Osing Tribe community. Osing community in Kemiren has no problem with women participating in the political process. However, in general society is of the opinion that no matter how high a woman's position is in social and political life, women should not leave their obligations in the family. Therefore, it is fine when women are in 
politics as long as they do not forget their obligations. In addition, women must continue to pay attention to their steps in politics so that they continue to act in the right direction. They must be able to present their dual role in public affairs (work) and not forget about domestic affairs in the family.

In interviews with the female village head, it was recorded that there were always obstacles when women became leaders. Sometimes the village communities is still not satisfied with the decision, their policies as village head and are always associated with their femininity. Nonetheless, it is also recognized as a common problem in leadership in which there are those who agree and disagree. Sometimes resistance to patriarchy must also be required, for example, one must explain if there are accusations; he or she cannot make decisions independently due to women, the ability to be a leader who is always compared to men, and so on. Constraints can be minimized when informants can wellbehave, make decisions and benefit the community.

One thing that should be appreciated by Osing women in Kemiren Village is that, in addition to maintaining traditional values, they still follow the national political culture. Women's political participation in Kemiren Village who has been qualified to exercise their voting rights has used it during the general election. The level of participation of Osing women in Kemiren Village can be said to be high, as they do not shut themselves off. They even accept that a campaign team visiting their customary village, offering their vision and mission. However, they answered politely that they would not take sides with one of the candidates, or could be said to be neutral but would still use their voting rights in elections, be it national or regional elections. The level of political consciousness of Osing women in Kemiren Village is quite high. It can be viewed from the level of political participation and the reasons for exercising voting rights. They exercised their right to vote on selfconsciousness and rather than from coercion or pressure from any outside party, as if there was a common thread connecting past records that identified the Osing people with high self-esteem, being honest, stubborn, and reluctant to work for Europeans. It is a cause of the low presence of Kemiren women in political parties. The above illustrates that the political interest of Osing women is still very low, as they do not want to be involved in practical politics. This condition is not much different from that of the men in Kemiren Village.

More clearly, the political construction of women in Osing Village is illustrated based on the research results; which is regarding the understanding of politics, the aims of women in politics, political communication they carry out, political participation, and whether there is a gender gap in them in terms of opportunities to gain access and benefits from politics thus far.

Table 3. Political construction of Osing women in Kemiren Village

\begin{tabular}{ll}
\hline \multicolumn{1}{c}{ Indicator } & \multicolumn{1}{c}{ Built-up construction } \\
\hline What is politics? & $\begin{array}{l}\text { Women in Kemiren understand politics, as they are accustomed to stories of politics, } \\
\text { conflicts, battles, and conquests from performances, stories, cultural performances, } \\
\text { such as Barong Kemiren performance. Nowadays, they get a lot of information } \\
\text { about politics from mass media. }\end{array}$ \\
Political participation \\
purposes
\end{tabular}$\quad \begin{aligned} & \text { Following the government's advice, the choice of following other family members, } \\
& \text { some feel politically permissible, as long as it is for the creation of Harmony in the } \\
& \text { people of Kemiren Village is created, ensuring the continuity of customs, traditions, } \\
& \text { and rituals of belief in the community. } \\
& \text { Political communication } \\
& \text { Open and independent, Women maintain good political communication, openly } \\
& \text { accept anyone with political interests, however, they do not overly respond to } \\
& \text { political mechanisms, leadership successions occurring at the national, district and } \\
& \text { village levels, such as during village head elections. } \\
& \text { Political participation } \\
& \begin{array}{l}\text { Fully ready to participate in politics, as there is no excuse for all women of all ages } \\
\text { failing to cast their votes as long as there is harmony in Kemiren society. } \\
\text { Gender gap }\end{array} \\
& \begin{array}{l}\text { Kemiren women with their education have their sense of equality to men. There is } \\
\text { no tradition that restricts it even if patriarchal resistance is often played in the Osing } \\
\text { ritual. }\end{array}\end{aligned}$

Source: processed research results (2020) 
The results of the above research indicate that social construction is built up due to the knowledge they obtain from values of their traditions, customs as well as education and experience. What an inter-subjective experience (inter-subjectivity) as stated by Peter L. Berger can be viewed in the political life of women in Osing community in Kemiren that is continuously formed. Knowledge also comes from experience, forming human understanding of society, which is the everyday world, sociality, and significance as Alfred Schutz explained in knowledge and significance, which later became the basis for Berger's thinking about knowledge [24].

Political stand and behavior of Osing women in Kemiren Village are built from their knowledge that is very much influenced by customs, traditions and social life that contain values of equality between men and women. This is what he meant that social phenomenon's are found in social experiences, which are continuously in process, lived in social life as a whole in all its aspects (cognitive, psychomotor, emotional, and intuitive).

In other words, social reality is implicit in social interactions, socially expressed in various social actions such as communicating through language, cooperating through forms of social organization. This kind of social reality is found in inter-subjective experiences. Concept of inter-subjective refers to structural dimensions of general consciousness to individual consciousness in a certain group that is mutually integrating and interacting [25]. Consciousness of women's political construction is built from an objective dimension as well as subjective dimension, as this society is actually a cultural creation of the community [26]. Every woman (individual) is the creator of objective social reality through a process of externalization, as objective reality re-affects humans through a process of internalization (reflecting subjective reality) in dialectic. Therefore, an egalitarian principle emerges between men and women in politics in Osing community in Kemiren. It is definitely interesting to study in which a society that upholds the values of forefathers and ancestors, there is no gender difference that results in the subordination of women in both the private and public sectors.

\section{CONCLUSION RECOMMENDATION}

AND

Construction of women in Kemiren Village who are participatory in politics is influenced by traditions, customs, cultures, and beliefs that they understand and believe. Resistance to the patriarchal culture that they see in the play performances, the traditional values and traditions that uphold the dignity of women, opens the barrier of awareness for equality. Women's construction in Kemiren is on par with men in politics, they have the same right to be elected. Most of Kemiren's women have not been independent in making their political choices, influenced by family members, community leaders. The low level of education is one of the factors besides the notion that harmony in society is more important than politics.

Women maintain good political communication, openly accept anyone with political interests, however, they do not overly respond to political mechanisms, leadership successions occurring at national, district and village levels, such as during village head elections. Fully ready to participate in politics, there is no excuse for all women of all ages failing to cast their votes as long as there is harmony in Kemiren community.

\section{REFERENCES}

[1] Indiarti, Wiwit. Wong Osing; Jejak Mula Identitas dalam Sengkarut Makna dan Kuasa. https://matatimoer.or.id/2018/04/17/wong-osingjejak-mula-identitas-dalam-sengkarut-makna-dankuasa/ (2018)

[2] Tim Historia. Menemukan Wong Osing. 29 Mei 2020. https://historia.id/kultur/articles/menemukanwong-osing-DwjxK

[3] Peter L Berger dan Thomas Luckman. Tafsir Sosial atas Kenyataan. Jakarta: LP3S (1990)

[4] Aimie Sulaiman. 2016. Memahami Teori Konstruksi Sosial Peter L. Berger, Jurnal Society, Volume VI, Nomor I, Juni (2016).

[5] Hasni, Khairul. Jurnal Perempuan untuk Pencerahan dan Kesetaraan. Perjuangan Panjang Perempuan dalam Budaya (2015)

[6] Kertati, Indra. Riptek Volume 8, No. I. Implementasi Kuota 30 Persen Keterwakilan Politik Perempuan di Parlemen (2014)

[7] Winter, Bronwyn. Religion, Culture and Women's Rights: Some general Political and Theoritical Consideration dalam Women's Studies International Forum, Vol 29, Issue 4, July-August 2006, p 381-393 (2006)

[8] Tripp, Aili Marry and Kang, Alice. The Global Impact of Quotas on the Fast Track to Increased Female Legislative Representation. Sage Journals Comparative Political Studies (CPS). http://cps.sagepub.com/content/41/3/338. (2008)

[9] El Saadawi. Perempuan di Titik Nol. Jakarta: Yayasan Obor. p: 2 (2014)

[10] Ritzer, G., \& Goodman, D. Teori Sosiologi Modern. Jakarta: Kencana (2004).

[11]Charles E Bressler. Literary Criticism: An Introduction to Theory and Practice 4th-ed. Pearson 
Education, Inc. ISBN-13:978-0-13-153448-3 (2007)

[12] Fineman, Martha Albertson. Symposium: Feminist Legal Theory Journal of Gender, Social Policy \& The Law. http://digitalcommons.wcl.american.edu (2005).

[13] Ollenburger, J. C., \& Moore, H. A. Sosiologi Wanita, terj. (B. Sucahyono \& Y. Sumaryana, Eds.). Jakarta: PT Rineka Cipta. p: 195 (2002)

[14] Munir, M. Pemilu, Demokrasi dan Ijtihat Politik Perempuan. Surabaya: Visipress (2004).

[15]Fakih, M., Megawangi, R., Saefuddin, A. M., Asa, S. R. D. S., Wahid, M. H. N., Mas'udi, M. F., \& Rachman, B. M. (2000). Membincang Feminisme: Diskursus Gender Pespektif Islam. Surabaya: Risalah Gusti (2000)

[16] Tong, R. P. Feminist Thought (terjemahan). Bandung: Jalasutra. p: 31 (1998)

[17]Lestari, Puji. Disertasi: Perempuan dalam Rekrutmen Legislatif di Jawa Tengah. p: 47. http://eprints.undip.ac.id/76067/3/BAB_II_PUJI_L ESTARI.pdf (2019).

[18]Lovenduski, J. Politik Berparas Perempuan. Kanisius. p:33 (2008)

[19] Astuti, Tri Marhaeni Pudji. Konstruksi Gender dalam Realitas Sosial. Semarang. Penerbit UNNES Press (2011)
[20] Nastiti, Titi Surti. Disertasi: Kedudukan dan Peranan Perempuan Dalam Masyarakat Jawa Kuna (Abad Viii--Xv Masehi) Http://Lib.Ui.Ac.Id/File?File=Digital/20164/130303-D623-Titi\%20surti\%20nastiti.Pdf P: 347 (2016)

[21]Lovenduski, J., Baudino, C., Sainsbury, D., Guadagnini, M., \& Meier, P. State Feminism and Political Representation. Cambridge University Press (2005)

[22] Angin, Ria dan Feridaa, Dwi Ratna. Prediktor Memilih Masyarakat Osing dalam Pemilu Tahun 2004. Jurnal Ilmu Sosial UM Jember (2004)

[23] Indiarti, Wiwit. Wong Osing; Jejak Mula Identitas dalam Sengkarut Makna dan Kuasa. https://matatimoer.or.id/2018/04/17/wong-osingjejak-mula-identitas-dalam-sengkarut-makna-dankuasa/ (2018)

[24] Sulaiman, Aimie. Memahami Teori Konstruksi Sosial Peter L. Berger. https://www.researchgate.net/publication/3353421 34_MEMAHAMI_TEORI_KONSTRUKSI_SOSI AL_PETER_L_BERGER

[25] op.cit.

[26] Basrowi dan Sukidin, 2002. Metode Penelitian Perspektif Mikro: Grounded theory, fenomenologi, Etnometodologi, Etnografi, Dramaturgi, Interaksi Simbolik. P: 201 (2002) 